Small and medium scale business performance in Nigeria:

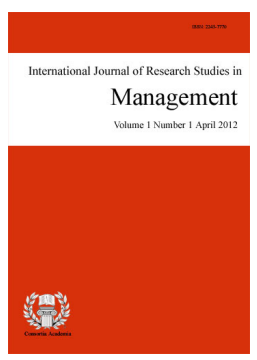

Eniola, Anthony Abiodun

Department of Business Management, University of Malaysia, Sarawak (UNIMAS), Malaysia (tony42003@vahoo.co.uk)

Entebang, Harry

Department of Business Management, University of Malaysia, Sarawak (UNIMAS), Malaysia

Sakariyau, Olalekan Busra

ISSN: $2243-7770$

Online ISSN: 2243-7789

Department of Business Management, University of Malaysia, Sarawak (UNIMAS), Malaysia

OPEN ACCESS

Received: 30 October $2014 \quad$ Revised: 29 December $2014 \quad$ Accepted: 4 June 2015

Available Online: 11 January 2015 DOI: 10.5861 /ijrsm 2015.964

\title{
Abstract
}

The contribution of small and medium enterprises in a knowledge-based economic system is very salient for the economic growth and development of a developing nation like Nigeria. The competitiveness of the SMEs in a knowledge-based economy is the main purpose of this study. One of the most important component sources of sustainable competitive advantage in intellectual capital is the application of human capital. The paper will reviews the challenges that are confronting the small and medium enterprises (SMEs) performance in Nigeria from this position. The paper will increase the savoir faire about the present concern relating to Small and medium enterprises in Nigeria and human capital value creation.

Keywords: SMEs; knowledge - based economy; performance; intellectual capital; human capital 


\section{Small and medium scale business performance in Nigeria: Challenges faced from an intellectual capital perspective}

\section{Introduction}

With the advance of the innovative era in the globalized and knowledge-based economy, to improve the performance development and competitiveness, small and medium enterprises (SMEs) desideratum is to acquire, monitor and manage intellectual capital (IC). According to resource-based theory Penrose (1959); Andrews (1971) as cited in Marr, Schiuma, and Neely (2004) organizations perform well and create value when they implement strategies that respond to market opportunities by exploiting their internal resources and capabilities. Therefore, intellectual capital (IC) is a key resource and the driver to improve business performance (J. Roos, N. Roos, Dragonetti, \& Edvinsson, 1997; Marr et al., 2004). The concept is Intellectual capital promotes competitive advantages that are the base of value generation (Edvinsson \& Malone, 1997; Bontis, 2001). Also, Intellectual Capital, of which human capital is believed to be a principal component, potent as the most significant etymology of maintaining competitive advantage (Nonaka \& Takeuchi, 1995; Edvinsson \& Malone, 1997; Sveiby, 1997; Seleim, Ashour \& Bontis, 2004; Cabrita \& Bontis, 2008). Human Capital refers to the right combination of intelligence, skills and expertise owned by an organization's employees. Essentially, this encapsulates: Intellectual capital - the knowledge individuals possess; Social capital - derived from both internal and external relationships between employees; and Organizational capital - the knowledge stored in organizational manuals and databases. Organization valuable asset are determined from the knowledge the workers attract to the establishment (Camuffo \& Comacchio, 2005).

Scholars surmise that SME performance is the lifeblood of the economic scheme by contributing to the economic growth of the country. Small and medium-sized businesses (SMEs) play a vital role in the economic growth of countries (Altenburg \& Eckhardt 2006; Lumpkin \& Dess, 1996; Wiklund \& Shepherd, 2005). Consequently, the performance of the SME sector is closely associated with the performance of the nation. Referable to the important contribution of SMEs to the growth of the nation's resources; the Nigerian government introduced a different strategy support policy program that presents a great deal of importance in raising the performance growth of SMEs. For improving the SMEs, schemes like industrial development center (IDC) are offered by the government with one of the primary targets of providing training to entrepreneurs and their staff, including management training to heighten SMEs performance and competitiveness. According to Odekunle (2001), investment in human capital has significant end on the impact of entrepreneurial ventures and technological innovation.

According to the resource based view, competitiveness is defined by the productivity with which a nation utilizes its human capital and natural resources. Macroeconomic viewpoints acknowledge human capital as the driver of national economic activity, competitiveness and prosperity (OECD, 1996). Hudson (1993) on an individual level, human capital is ensured as a portmanteau word of four elements: genetic inheritances, education, experience and attitudes about life and business (Edvinsson \& Malone, 1997; Sveiby, 1997; Seleim, Ashour, \& Bontis, 2004). Scholars posited that the blend knowledge of workers in an establishment produces a competitive advantage for the firm (Barney, 2001; Barney et al., 2001; Marr \& Spender, 2004; Schiuma et al., 2007; Kang \& Snell, 2009; Kong \& Thomson, 2009). According to Kong and Thomson (2009) the collective cognition of an organization is of extremely salient in today's knowledge based economic system. Intellectual capital (IC) makes up the collective knowledge implanted in the human resources, firm procedures and network connection of an establishment. Being the main element of intellectual capital in achieving and maintaining competitive advantages; human capital has been admitted as fundamental resources that require development of an organization (Edvinsson \& Malone, 1997; Seleim, Ashour, \& Bontis, 2004; Chen, 2008; Kong \& Prior, 2008). According to Drucker (1993) and Bornemann et al., (1999) argue that knowledge which supplant land, labor and 
capital is the only significant resources for business operation.

Nigeria today has the biggest economy in Africa. According to the national planning commission of Nigeria, the country is in progress of achieving vision 20:2020 of improving the pace of economic development by transforming from industry based to knowledge based economy and be among the twenty leading economies of the world come year 2020 (Ebiringa \& Okorafor, 2010) the contribution performance of the SMEs is considered as the backbone (Ariyo, 2008). SMEs provide over $90 \%$ of employment opportunities available in the manufacturing sector and account for about $70 \%$ of aggregate employment created per annum (Eniola \& Ektebang, 2014). Yet, against international best practices Nigeria is rated poorly due to the core component dearth of intellectual capital in the public figure of human capital (innovation, operation and customer capital) of the SMEs owners (Nielson et al., 2006). The paper therefore, reviews the challenges that are confronting the small and medium enterprises (SMEs) performance in Nigeria from this position.

\section{SMEs in Nigeria}

A proper definition of SMEs is important to distinguish between the different categories of the production units in terms of factors like; number of employees, the value of fixed assets, production capacity, basic characteristics of the inputs, level of technology used, capital employed, management characteristics, etc. Scholars have argued that there is no general accepted definition of small or medium businesses because of the classification of businesses into large, medium or small scale is a subjective and qualitative judgment (Eniola, 2014). It is hard to develop a general definition of a small concern because the economies of countries differ, and people take on particular standards for special uses. Different institutions and nations use different standards to define SMES. Because, a lot of their bodily processes depend on the industry in which they operate, also, the personalities and ambitions of those in charge of these businesses.

In Nigeria, the CBN puts the employment level of the small scale businesses at less than 50 and medium scale businesses as less than 100. In terms of asset-based, small scale has less than $\mathrm{N} 1$ million, while medium scale has less than N150 million (IFC, 2002). Classification in USA, Britain and Canada defined SMEs in terms of annual turnover and the number of paid employees whereas it is conceptualized in Japan as an industry paid up capital and the number of employees.

The Federal Ministry of Industries defines a medium-scale enterprise as any company with operating assets less than N200 million and employing less than 300 persons. A small-scale enterprise, on the other hand, is one that has total assets of less than N50 million, with less than 100 employees. Annual turnover will not be given consideration in the definition of an SME. The National Economic Reconstruction Fund (NERFUND) defines an SSE as one whose total assets are less than N10 million, but makes no reference either to its annual turnover or the number of employees. These and other definitions of the National Association of Small Scale Industries (NASSI), the National Association of Small and Medium Enterprises (NASME), the Central Bank of Nigeria $(\mathrm{CBN})$. The Small and Medium Industry Equity Investment Scheme (SMIEIS), defined an SME as any enterprise with a maximum asset base of N500 million, excluding land and working capital and with the number of employees not less than 10 or more than 300. This definition did not distinct between small and medium scale enterprises (Sanusi, 2003).

\section{Table 1}

Classification Adopted by SMEDAN for National Policy on MSMEs

\begin{tabular}{llll}
\hline S/N & \multicolumn{1}{c}{ Size category } & \multicolumn{1}{c}{ Employment } & \multicolumn{1}{c}{ ASSETS (N million) (excluding land and } \\
buildings)
\end{tabular}




\section{Human Capital and SME performance}

Bruderl et al. (1992) were the first researchers to fit human capital theory in the entrepreneurial context by arguing that although the general application of human capital is on employees, there is no reason why it should not apply to entrepreneurs as well. Accordingly, entrepreneurs with higher general and specific human capital can be expected to show higher levels of performance than those with lower levels of general and specific human capital. This is termed as entrepreneurial human capital.

According to Hessels and Terjesen (2008), entrepreneurial human capital is the combination of an individual's knowledge, skills and experiences linked to entrepreneurial activity. Entrepreneurial human capital is substantial and consequential to entrepreneurial growth. Ganotakis (2012) applied the resource based theory (RBT) to develop the value of human capital to entrepreneurship. Accordingly, human capital is examined to be an important source of competitive advantage for entrepreneurial organizations.

Human capital is one of the important dominant forms in the field of intellectual capital. Royal and O'Donnell (2008) said that human resource capital is a really important ingredient of value creation. It is the dimension of intellectual capital which deals with the human knowledge and its experience. It is the employees who offer businesses with experience and expertise, educational qualifications and occupational competencies. Employee knowledge and capabilities are the significant roots of innovation (Wang \& Chang, 2005).

It is appropriate to infer that human capital closely influences innovation capital. Bontis (1998) emphasizing the organizational view, allude to human capital as the important root of innovation and strategic transformation. A scholar in the field of modern management, Kanter, has focused on the pressing need for innovation. Previous surveys demonstrate that intellectual capital is connected with an organization's innovative success (Subramaniam, \& Youndt, 2005; Wu, Chang, \& Chen, 2008; Zerenler, Hasiloglu, \& Sezgin, (2008). Kanter (1989) develops a model centers on large corporations retaining the flexibility and dynamism of their entrepreneurial youth. Employees are needed to carry out the internal process of a firm. People hand over customer service and create brand connections, as well as build customer lists and desirable products. People are likewise the source of intellectual property while being the mainsprings of corporate culture and knowledge networks. By providing quality service while implementing internal processes, the capability of employees would affect process efficiency and customer satisfaction (Wang, \& Chang, 2005). According to human capital theory, people are viewed as valuable resources, and emphasizes that investment by firms in human will produce meaningful returns. The concept views workers as key resource managers used to achieve competitive advantage for their companies (Fombrun et al., 1984). Stewart (1997) focused on the relationship between customers and employee capabilities. He pointed out that employees should have suitable knowledge or skills to serve client demands.

According to Bontis (1998); Wang and Chang (2005) human capital affect business performance through innovation capital, process capital and customer capital. Bontis (1998) customer capital is determined as the knowledge embedded in the marketing channels and client relationships. Customer capital mainly based on marketing capability, customer commitment, and relationship with customer and customer satisfactions (Amiri et al., 2010). Process capital is the value to an enterprise which is deduced from the techniques, processes, and programs that implement and enhance the legal transfer of goods and services. It can be created and enhanced by through business process management (Brocke \& Rosemann, 2010).

Structural Capital is everything in an organization that supports employees (Human Capital) in their work. According to Skandia's model, the hidden factor of human and structural capital is an assortment of intellectual capital with added together. Sharifirad and Ataei, (2012) put forward that creativity and innovation are important to encourage invention and this situation is driven by the culture of the system. It implies that organizational culture is the essence of innovation. It would be the one in which entrepreneurs are motivated and positive enough to continually test new things out. On the other hand human capital is explained as the blend of 
innovation capital, process capital and customer capital. Human capital is the ability of company's individual employees to take on the task at hand (Bhatt, Gupta, \& Kitchens, 2005). Royal and O'Donnell (2008) determines the clamp of human capital in the community between the capital and knowledge management, reflecting the human capital is the backbone of intellectual capital.

Chen, Cheng \& Hwang (2005) found that intellectual capital and physical capital have a positive impact on market returns, in addition to current and future financial performance. This was corroborated by Tan, Plowman \& Hancock, (2007) in their study using the publicity trade companies in Singapore. El-Bannany (2008) suggests that the investment in intellectual capital variables has a substantial impact on firm performance. Figure 1, shows the links between the human capital components and SME firm performance.

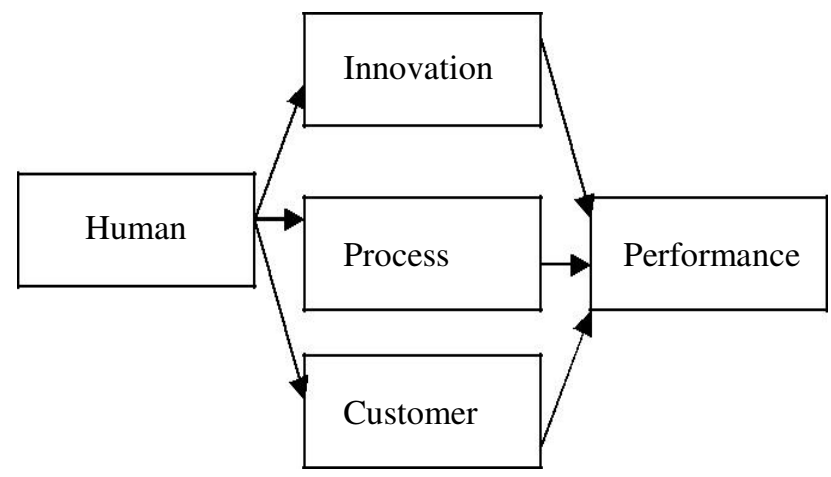

Figure 1. Human capital components and SME firm performance

Source. Wang and Chang (2005)

\section{SMEs Performance Contribution in Nigeria}

Marr and Schiuma (2001) posit that Intellectual capital is the group of knowledge assets that are attributed to an organization and most significantly contribute to an improved competitive position of this organization by adding value to defined key stakeholders." Nowadays, the intellectual capital and knowledge management are both importance by the organizations. The differentiation between knowledge management and intellectual capital - knowledge management is a process surround within a company and intellectual capital covers whole operations of all organizations.

Nigeria, has the leading economy in Africa is in progress of transforming from industry based on the knowledge based economy and be among the twenty leading economies of the world come year 2020, the contribution performance of the SMEs is considered as the spinal column. Nigeria SMEs is extremely important and contribute significantly to the economic growth, particularly, the manufacturing sectors. SMEs comprise about $70 \%$ to $90 \%$ of the business establishment in the manufacturing sector in Nigeria (Eniola \& Ektebang, 2014). Moreover, the potential of SMEs is to serve as an engine for wealth creation, employment generation, entrepreneurial skills development, and sustainable economic development. SMEs is the creativity and ingenuity of entrepreneurs in the utilization of the abundant non- oil, natural resources of this nation will provide a sustainable platform or springboard for industrial development and economic growth as is the case in the industrialized and economically developed societies (Eniola \& Ektebang, 2014). SME provides over $90 \%$ of employment opportunities available in the manufacturing sector and account for about $70 \%$ of aggregate employment created per annum (Ebiringa, 2011; Eniola \& Ektebang, 2014).

The 2014 Global Competitiveness Index (GCI) published placed Nigeria in 127th position, a further downfall of seven places to 120th position in 2013. This result pointed out that institution in Nigeria remained weak with a ranking of 129th position out of 144 countries, due to insufficiently protect intellectual property. Other factors that led to the country's drop in the GCI are high corruption, undue influence, security, infrastructure as well as non-betterment in its health and primary education. Though, the country boast of substantial financial market ranked 67th out of 144 nations, following its gradual recovery from the 2009 
financial crisis. Nevertheless, the country ranked 137th position as poor availability and affordability of finance in general and the difficulties in getting loans in particular still remain an important bottleneck to economic development. Furthermore, the state is not tackling the latest technologies for productivity enhancements, as proven by its low rates of ICT penetration. These affirm the fact that the Nigerian SMEs firm has not fully enhanced his intellectual capital (human capital). As a result, the firm would fold-up due to their inability to manage and nurture their intellectual resources (Antal et al., 1994).

Brennan and Connell (2000) stated that SME is more than the proprietorship or the founder; it is about the people who make things going and make a profit for the organization. The most important in human capital is about what people can do, individually and collectively. According to Abernathy et al. (2003) as cited in Salman et al. (2012) estimate that investment in intellectual capital yields twice returns as compared to the same amount of investment in physical assets. The top ranked10 Asian companies between the periods of 1995 to 2001 were those companies that create value to their shareholders through intellectual capital (Salamudin et al., 2010). Specifically, these companies' investments are focused on human capital and network effect rather than physical capital (Tseng \& Goo, 2005; Makki et al., 2009). Mostly, electronics companies, service companies, technology companies and biochemical do engage more of intellectual capital resources than other companies. For example, the Toshiba electronic company achieved $20 \%$ higher productivity after adopting intellectual capital management (ICM) strategy in its factory (Fruin, 1997).

According to SMEDAN and NBS (2010) over the past years, the total registered SMEs in Nigeria indicate around 15,000 to 23,000 within the various ministries. Small and medium enterprises are the widest- different form of a business creation in Nigeria, and they largely lead in raw material, mining and quarrying, building and construction, general business, agriculture, and manufacturing sector. In 2012, the Presidential budget speech, the President of the Federal Republic of Nigeria reiterated the crucial role of the SMEs to the economy. SMEs performance growth promotion via several fiscal policies has been publicized. Consequently, operating role of SMEs in the manufacturing sector is quite more noteworthy in the Nigeria economy (Nigeria Vision 20: 2020-National Planning Commission, 2010; Okongwu, 2001). According to the Nigeria Vision 20: 2020-National Planning Commission (2010), SMEs contributed $10 \%$ of the GDP, in 2009 the figures, though weak, is expected to increase significantly in the future through various strategies put in place by government.

There is a significant acknowledge of the contributing performance function of SMEs in the manufacturing sector. In Nigeria, SMEs in the manufacturing sector is mainly entangled in ventures like food and beverage; metal, iron \& steel; paper, printing \& publishing; chemicals, paints, pharmaceuticals \& plastics; textiles, garments \& leather; wood, furniture \& paper; automobile components and assembly; tanning; fabricators; foundry, etc. (SMEDAN, 2010; SME Sector National Technical Working Group, 2009). Geographically, manufacturing entity, generally, is operating in the southerly region of Nigeria. Two states, namely LagosOtigba - SME Clusters and Nnewi - SME Clusters are the focal point of SMEs, which concentrate on ICT and the automobile manufacturing sector in Nigeria (Oyelaran-Oyeyinka, 2010). The SME importance of ICT and automobile manufacturing in Nigeria is constructive significantly to the economic system.

Oyelaran-Oyeyinka (1997) Ogundele et al. (2014), the Nnewi Automotive Parts Industrial Cluster is a huge success story in Nigeria, and It is a very sound instance of how an informal cluster can hold out and succeed without government financial backing in terms of provision of indispensable public service programs. Local traders creating an employment opportunities transformed themselves into producers of automobile parts through close linkages to technology suppliers in Asia country, Taiwan. Most of these firms have the design capability to modify products and adapt the production process to the local market. This industrial cluster exports automotive parts to West African countries sub-area as well as other international destinations. Its major critical success factors include active participation of private industry associations, characterized by investment preparation, capability to imitate and assimilate foreign technology, high entrepreneurial spirit, as well as competitiveness. Above all, the Nnewi cluster made a self-standing effort to provide the needful infrastructural support when the state failed to act thus, and firms perform, survive and grow despite major infrastructural and financial provision 
constraints.

The Otigba SME ICT raceme is a more recent development, increasing the cluster of meeting regional West African market demand with some 392 SMEs employing more than 3000 workers' (Oyelaran-Oyeyinka 1997; Ogundele et al. 2014). The substantial inter-firm cooperation and joint activity is characterized by cluster development. A key element at play in this cluster looks to be the relatively very high educational level of the workforce. The fact that many of the skilled workers have ties with one another going back to their school or college has led to a high degree of commercial trust among the firms in the yearning for the provision of supplier credits among firms in the cluster, including, know-how exchange and joint warehousing. These sectors are measured as value advantage and high knowledge intensive.

\section{Development of Human capital like empowerment in Nigeria}

In the new economy, which is knowledge-based or knowledge economy; value creation become one of the crucial issues in the world and tends to be based on intangible rather than tangible assets. According to Al-Ali (2003), in the knowledge economy, companies' capital and resources consists of $80 \%$ of intangible assets and resources and $20 \%$ of tangibles. In Nigeria, the development of human capital like empowerment of the human mentality and intellectual capacity of the nations is one of the targeted area or government focus under the First medium term plan (NIP 2010-13).

In the preface of the First medium term plan (NIP 2010-13), there is going to be a shift in the growth strategy from being input-driven towards one that is knowledge-driven" to achieve the vision 2020 of becoming a developed nation (Abdulai, 2004; Bhatiasevi, 2010). The major focus is on the development of the required knowledge infrastructure, as well as a framework for the development of knowledge-driven economy. The four areas of focus are, human resource development; investment in ICT to Postal Services and Science, Technology and Innovation. In achieving vision 2020 and to be among developed and industrialized nation, the development of SMEs performance should be primarily focused as the future advancement.

According to Imiefoh (2012), the fifth plenary session of the fifteenth congress of the communist party of Nigeria recently made it clear that the development of knowledge- based industry should be the driving force for industrialization; the late-take-off advantage should be engaged to achieve a leap-forward development of the social productivity. That is, and the process of economic globalization and web-based information flow will be further sped up. Nigeria will be introducing the era of creating a relatively comfortable life for all the citizens and speeding up the modernization effort. Thus, for a Nigeria economy to successfully be carried out along the foundation of knowledge to fit the demands of people both locally and globally, it is expedient to lay out in motion necessary mechanisms, to carry out a program of action and embrace e-strategies. Nigeria trade balance, jobs structures, lifestyles, and emerging businesses, form a new competitive advantage in global business.

According to Van Eeden et al. (2004); Muhammad et al., (2010) many previous studies, Kwanashie (1998), Egware (1998) and Aninat (2002); Saleh and Ndubisi (2006); Rogerson (2008); Aris (2006); Harvie (2004); Wang (2003); National Planning Commission (2009); Wafa et al. (2005); Decker et al. (2006); and SMEDAN (2007), identified different obstacles faced by SMEs in a world environment. The SMEs should mainly concentrate on defeating the various barriers mitigating against the performance, which includes lack of financing, lack of deterrent from global sourcing, managerial capabilities, low productivity, recession, difficulty in getting access to management, heavy regulatory burden and technology innovation. Chigbo (2006) and Van Aardt et al. (2008) identified impediments to entrepreneurship growth as, lack of access to formal business, lack of financing and networking.

In a knowledge-based economy, intellectual capital becomes the major important and incisive resources for an establishment to thrive in a competitive clime. Ding and Li (2010) posit that intellectual capital is imperceptibly evolving the physical resources in contemporary enterprises. It is imperative for advanced and sophisticated initiatives to pay full attention not only on product development, marketing mix, market and 
services, likewise, they demand to augment advancement in the research and development competence to market the product, and be mindful the management of the organization human capital. Shaari et al. (2010), Leitner (2011) and Bataineh and Zoabi (2011) postulated that intellectual capital is a really significant element for an establishment to reach eminence and to gain a competitive advantage. Thus, it is examined that intellectual capital is a very fundamental resource in a knowledge-based economic system, grounded on the cited literature review.

\section{Challenges of SMEs Performance in Nigeria}

Resource-based theory has been developed to understand how organizations achieve sustainable competitive advantages. Within the resource-based view (RBV), researchers assumed that the firm is a pool of hard-to- copy resources and capabilities (Conner, 1991) and those discrepancies in size distribution and competitiveness of firms occur from their distinctive capabilities to build up, expand, and organize those resources and capabilities to create and apply value-enhancing strategies (Amit \& Schoemaker, 1993; Peteraf, 1993). In the resource-based view (Wernerfelt, 1984; Prahalad \& Hamel, 1990; Peteraf, 1993; Conner, 1991), knowledge is viewed as a strategic advantage with the potential to be the bedrock of sustainable competitive asset for an establishment. The knowledge-based view of the firm (Grant, 1995, 1996) builds upon and extends the resource-based theory of the firm initially promoted by Penrose (1959) and expanded by others (e.g., see Alavi \& Leidner 2001). It encompasses the facets to knowledge integration (efficiency, scope and flexibility) and the four primary mechanisms by which knowledge is coordinated; rules and directives, sequencing, routines and group problem solve and decision making.

Regardless of nations, SMEs confronts familiar challenges within the reality of performance and to acquire competitive advantage. Records indicate that more than 50\% of SMEs did not survive within first five years of gestation period (Dinh et al., 2011; Kpleai, 2009; Ou \& Haynes, 2006; Reiss, 2006; Ahmad \& Seet, 2009). In Nigeria event, report shows that $85 \%$ out of $100 \%$ of established enterprises did not survive beyond five years of enterprise (Aremu \& Adeyemi, 2010; Ariyo, 2008; Aterido et al., 2007; Basil, 2005; Dinh et al., 2011; Kpleai, 2009; Ou \& Haynes, 2006; Ogunjuiba et al., 2004). It affirms that small and medium business in Nigeria is confronting with severe and various challenges to remain competitive in the market. Nigeria is now accessing into a knowledge-based economy. The world challenges have made it significant for Nigeria to steer in the direction of knowledge-based economy (Doouas, 2001; Wade, 2001; Calamitsis, 2001; Gondwe, 2001; Bhatiasevi, 2010).

Technology sophistication in terms of innovation can give SMEs a better opportunity to compete in the markets and soon this will be a competitive necessity for survival in all organizations. At the moment lack of Nigerian government policies that support technology adoption and integration in SMEs appear to be under performing and less competitive due to electricity and financial constraints among others (Adenikinju, 2005; Musawa \& Wahab, 2012). Folorunso, Olusegun, Gabriel, Awe, Sharma, Sushil, and Zhang, (2006) acknowledged human capital (education), cost of implementation of the technology and the rest. Kuteyi (2009) as cited in Musawa and Wahab (2012) identified lack of funding and non-utilization of Technology as one of the major policy factor that affect the developments of Nigerian SMEs. Ovia (2000) have categorized internal and external barriers that impede adoption of technology by SMEs in a developing country. The internal barriers include entrepreneur characteristics, firm characteristics, cost and return on investment, and external barriers include: infrastructure, social, cultural, political, legal and regulatory. It has long been established that modern economies depend more, for their development and growth, on the intellectual capital possessed by their managers than on the quantum of natural resources available to a nation.

Shortage of resources, along with the lack of non-core expertise, is a key threat for innovative SMEs. SMEs do not deficient only in physical assets, but also management transparency resources that financial institutions can use as collateral (Brant \& Lohse, 2013). In addition, SMEs may confront a host of other internal and external constraints, like lack of scale, competition and market entry problems, inadequate infrastructure, and lack of 
distribution channels and marketing expertise. It has been proposed that the international aid Scheme for SMEs be revamped to focus to a larger extent on the provision of training for individual SME owners, in addition to enhancing 'investment climate refine' that promote the overall environment for executing business (Page \& Söderbom, 2012). Designed training can help innovative SMEs managers to address internal constraints and lure partners and investors, through intellectual capital management. Likewise, training assists to glean more value from the firms' innovation and collaborations.

Modern technologies drive all aspects of innovative economic activities, for optimum efficiency and greater productivity, so is human capital a critical driver of all strong national economic organizations. SMEs that invent are much nearer to source of technological ken, like the universities or research centers (Vaona \& Pianta, 2008). Therefore, they lean to perform particularly well when innovation depends on being resolute to science (Revilla 2012). Costello and Sloane (2003) said that SMEs hindered in adopting technologies because of the barriers that arises in the organizations. Iacovou et al. (1995) stated that lack of awareness among owner-managers, lack of skills and training, cultural element, lack of government policies that support IT adoption and integration in SMEs (Adenikinju, 2005). The state of infrastructures, poses a major hindrance to the use of Technology innovation in Nigeria (Musawa \& Wahab, 2012). Other factors Olatokun and Kebonye (2010) such as the size of the enterprise and the type of business enterprise could also affect.

In distinction, bigger firms are more secure and able to spread the cost of innovation and process capital over a larger scale and varied sales base. New innovators often experience financial stress at inception, especially in establishments with venture capital (VC) system deficient, as they resort regularly to the more costly debt markets. Information asymmetries between entrepreneurs and investors, which ensued in the latter, or inability to appropriately assess innovative projects, deepen these problems (Brant \& Lohse, 2013). Large firm, oft bear the resources, experience, and skills needed to effectively market new offerings, which yield them an edge where knowledge is accruing (Revilla \& Fernández, 2012). Ultimately, the impact of litigation is less threatened, the budgetary value experience can deliver a devastating impact on SMEs (Friesike, Gassmann \& Krogh, 2012). While smaller firms may be more dexterous and rely upon the environments; more innovative, bigger firms revel in resource advantage.

Hashim and Wafa, (2002), Wang and Wu, (2011) and Muhammad et al. (2010) argued that the primary problems faced by SMEs are the lack of technology knowledge regarding marketing techniques, branding, customer dedication and also lack of good contacts with others locally and international initiatives. Alam et al. (2011) observed that SMEs in Nigeria have social barriers that are main obstacles to achieve a competitive advantage and consequently many SMEs in Nigeria lose out in terms of opportunities.

\section{Conclusion and Recommendations}

From the paper, it can be imprecise deduced that intellectual capital via human capital viewed has the unguent of any system to evolve into competitive in a knowledge-based economy. On that point is no dubiety that the relevance to SMEs performance for economic progress is highly acknowledged in the world without uncertainty. Empirical evidences of SMEs performance, not provided for this study, but at least, I conceive it will add in inclusion of literature review and knowledge concerning SMEs knowledge- based performance in Nigeria. The future-focused should be on empirical studies in this field. Summary of this paper was to provide the overview of challenges of SMEs in Nigeria. However, it is implied that in a knowledge-based economy, the intellectual capital appears as most crucial influence for the accomplishment of any organization.

\section{References}

Abdulai, D. (2004). Can Malaysia transit into the K-economy? Dynamic challenges, tough choices, and the next phase. Subang Jaya, Selangor Darul Ehsan: Pelanduk Publications.

Adenikinju, A. F. (2005). Analysis of the cost of infrastructure failures in a developing economy: The case of the 
Eniola, A. A., Entebang, H., \& Sakariyau, O. B.

electricity sector in Nigeria. Nairobi, Kenya: African Economic Research Consortium.

Ahmad, N. H., \& Seet, P. S. (2009). Dissecting behaviours associated with business failure: A qualitative study of SME owners in Malaysia and Australia. Asian Social Science, 5(9), 98-104. http://dx.doi.org/10.5539/ass.v5n9p98

Al-Ali, N. (2003). Comprehensive intellectual capital management: Step-by-step. Hoboken, NJ: Wiley.

Alam, S. S., Jani, M. M., Senik, Z. C., \& Domil, A. A. (2011). Assessing barriers of growth of food processing SMIs in Malaysia: A factor analysis. International Business Research, 4(1), 252-259.

Altenburg, T., \& Altenburg, U. (2006). Productivity enhancement and equitable development: Challenges for SME development. Retrieved from http://www.unido.org/fileadmin/import/59567_06COMPID_0591423_Ebook.pdf

Amiri, N. A., Majid, R., \& Omrani, A. (2010). Studying the impacts of organizational organic structure on knowledge productivity effective factors case study: Manufacturing units in a domestic large industrial group. European Journal of Scientific Research, 40(1), 91-101.

Amit, R., \& Schoemaker, P. J. (1993). Strategic assets and organizational rent. Strategic Management Journal, 14(1), 33-46. http://dx.doi.org/10.1002/smj.4250140105

Ariyo, D. (2008). Small firms are the backbone of the Nigerian economy. Retrieved from http://www.AfricaEconomicAnalysis.org

Barney, J., Wright, M., \& Ketchen, D. J. (2001). The resource-based view of the firm: Ten years after 1991. Journal of Management, 27(6), 625-641. http://dx.doi.org/10.1177/014920630102700601

Barney, J. B. (2001). Is the resource-based "view" a useful perspective for strategic management research? Yes. The Academy of Management Review, 26(1), 41-56.

Bhatiasevi, V. (2010). The race towards a knowledge based economy a comparative study between Malaysia and Thailand. International Journal of Business and Management, 5(1), 114-122.

Bhatt, G., Gupta, J. N., \& Kitchens, F. (2005). An exploratory study of groupware use in the knowledge management process. Journal of Enterprise Information Management, 18(1), 28-46. http://dx.doi.org/10.1108/17410390510571475

Bontis, N., \& DeGroote, M. G. (2001). Assessing knowledge assets: a review of the models used to measure intellectual capital. International Journal of Management Reviews, 3(1), 41-60. http://dx.doi.org/10.1111/1468-2370.00053

Bontis, N. (1998). Intellectual capital: an exploratory study that develops measures and models. Management Decision, 36(2), 63-76. http://dx.doi.org/10.1108/00251749810204142

Bontis, N. (2002). Managing organizational knowledge by diagnosing intellectual capital: framing and advancing the state of the field. In The strategic management of intellectual capital and organizational knowledge (p. 621-642). Oxford: Oxford University Press.

Bornemann, M., Knapp, A., Ursula Schneider, U., \& Sixl, K. I. (1999, June 9). Holistic measurement of intellectual capital. Paper presented at the International Symposium Measurement and Reporting Intellectual Capital: Experiences, Issues and Prospects. Retrieved from http://www.oecd.org/industry/ind/1947871.pdf

Brant, J., \& Lohse, S. (2013). Enhancing intellectual property management and appropriation by innovative SMEs (450/1081-1). Retrieved from International Chamber of Commerce (ICC) website: file://C:/Users/User/Downloads/PIA_SME_ENG_WEB\%20(3).pdf

Brocke, J., \& Rosemann, M. (2010). Handbook on business process management. Berlin: Springer. http://dx.doi.org/10.1007/978-3-642-00416-2

Bruderl, J., Preisendorfer, P., \& Ziegler, R. (1992). Survival chances of newly founded business organizations. American Sociological Review, 57(2), 227-242. http://dx.doi.org/10.2307/2096207

Cabrita, M. D., \& Bontis, N. (2008). Intellectual capital and business performance in the Portuguese banking industry. International Journal of Technology Management, 43(1-3), 212-237. http://dx.doi.org/10.1504/IJTM.2008.019416

Camuffo, A., \& Comacchio, A. (2005). Linking intellectual capital and competitive advantage: A cross-firm competence model for north-east Italian SMEs in the manufacturing industry. Human Resource 
Development International, 8(3), 361-377. http://dx.doi.org/10.1080/13678860500149951

Chen, M., Cheng, S., \& Hwang, Y. (2005). An empirical investigation of the relationship between intellectual capital and firms? Market value and financial performance. Journal of Intellectual Capital, 5(2), 159-176.

Chen, Y. (2008). The positive effect of green intellectual capital on competitive advantages of firms. Journal of Business Ethics, 77(3), 271-286. http://dx.doi.org/10.1007/s10551-006-9349-1

Conner, K. R. (1991). A historical comparison of resource-based theory and five schools of thought within industrial organization economics: Do we have a new theory of the firm? Journal of Management, 17(1), 121-154. http://dx.doi.org/10.1177/014920639101700109

Drucker, P. F. (1993). Post-capitalist society. Oxford: Butterworth-Heinemann.

Ebiringa, O. T., \& Okorafor, G. F. (2010). Effects of human capital development on the performance of small and medium scale enterprises in the south-eastern region of Nigeria. Journal of Sustainable Development in Africa, 12(8), 49-58.

Edvinsson, L., \& Malone, M. S. (1997). Intellectual capital: Realizing your company's true value by finding its hidden brainpower. New York: Harper Business.

Eeden, S. V., Viviers, S., \& Venter, D. (2004). An exploratory study of selected problems encountered by small businesses in a south African context. Journal of African Business, 5(1), 45-72. http://dx.doi.org/10.1300/J156v05n01_04

El-Bannany, M. (2008). A study of determinants of intellectual capital performance in banks: the UK case. Journal of Intellectual Capital, 9(3), 487-498. http://dx.doi.org/10.1108/14691930810892045

Eniola, A. A., \& Ektebang, H. (2014). SME firms performance in Nigeria: Competitive advantage and its impact. International Journal of Research Studies in Management, 3(2), 75-86. http://dx.doi.org/10.5861/ijrsm.2014.854

Folorunso., Olusegun., Gabriel., Awe, O. G., Sharma., Sushil, K., \& Zhang, J. (2006). Factors affecting the adoption of e-commerce: A study in Nigeria. Journal of Applied Sciences, 6(10), 2224-2230. http://dx.doi.org/10.3923/jas.2006.2224.2230

Fombrun, C. J., Tichy, N. M., \& Devanna, M. A. (1984). Strategic human resource management. New York: Wiley.

Friesike, S., Gassmann, O., \& Krogh, G. (2012). Profiting from innovation by managing intellectual property. St. Gallen.

Ganotakis, P. (2012). Founders' human capital and the performance of UK new technology based firms. Small Business Economics, 35(4), 1-21.

Hashim, M. K., \& Wafa, S. A. (2002). Small and medium-sized enterprises in Malaysia: Development issues. Prentice Hall: Pearson Malaysia Sdn Bhd: Kuala Lumpur.

Hessels, J., \& Terjesen, S. (2008). Entrepreneurial career capital, innovation and new venture export orientation. Scales Research Reports, 1-34.

Hudson, W. J. (1993). Intellectual capital: How to build it, enhance it, use it. New York: J. Wiley.

Iacovou, C. L., Benbasat, I., \& Dexter, A. S. (1995). Electronic data interchange and small organizations: Adoption and impact of technology. Management Information Systems Quarterly, 19(4), 465-485. http://dx.doi.org/10.2307/249629

Imiefoh, P. (2012). Knowledge based economy in Nigeria: The role of ICT. Journal of Emerging Trends in Engineering and Applied Sciences, 3(2), 315-318.

Kang, S., \& Snell, S. A. (2009). Intellectual capital architectures and ambidextrous learning: A framework for human resource management. Journal of Management Studies, 46(1), 65-92. http://dx.doi.org/10.1111/j.1467-6486.2008.00776.x

Kong, E., \& Prior, D. (2008). An intellectual capital perspective of competitive advantage in non-profit organisations. International Journal of Non-profit and Voluntary Sector Marketing, 13(2), 119-128. http://dx.doi.org/10.1002/nvsm.315

Kong, E., \& Thomson, S. B. (2009). An intellectual capital perspective of human resource strategies and practices. Knowledge Management Research \& Practice, 7, 356-364. 
Eniola, A. A., Entebang, H., \& Sakariyau, O. B.

http://dx.doi.org/10.1057/kmrp.2009.27

Kong, E. (2008). The development of strategic management in the non-profit context: Intellectual capital in social service non-profit organizations. International Journal of Management Reviews, 10(3), 281-299. http://dx.doi.org/10.1111/j.1468-2370.2007.00224.x

Lumpkin, G. T., \& Dess, G. G. (1996). Clarifying the entrepreneurial orientation construct and linking it to performance. The Academy of Management Review, 21(1), 135-172.

Marr, B., \& Schiuma, G. (2001). Measuring and managing intellectual capital and knowledge assets in new economy organisations. In Bourne, M. (ed.), Handbook of performance measurement (pp. 1-30). London: GEE Publishing.

Marr, B., \& Spender, J. (2004). Measuring knowledge assets - implications of the knowledge economy for performance measurement. Measuring Business Excellence, 8(1), 18-27. http://dx.doi.org/10.1108/13683040410524702

Marr, B., Schiuma, G., \& Neely, A. (2004). Intellectual capital - defining key performance indicators for organizational knowledge assets. Business Process Management Journal, 10(5), 551-569. http://dx.doi.org/10.1108/14637150410559225

Marr, B., Schiuma, G., \& Neely, A. (2004). The dynamics of value creation: mapping your intellectual performance drivers. Journal of Intellectual Capital, 5(2), 312-325. http://dx.doi.org/10.1108/14691930410533722

Muhammad, M. Z., Char, A. K., Yasoa, M. R., \& Hassan, Z. (2010). Small and medium enterprises (SMEs) competing in the global business environment: A case of Malaysia. International Business Research, $3(1), 66-75$.

Musawa, M. S., \& Wahab, E. (2012). The adoption of electronic data interchange (EDI) technology by Nigerian SMEs: A conceptual framework. E3 Journal of Business Management and Economics, 3(2), 55-68.

Nonaka, I., \& Takeuchi, H. (1995). The knowledge-creating company: How Japanese companies create the dynamics of innovation. New York: Oxford University Press.

Odekunle, S. O. (2001). Training and skill development as determinant of workers' productivity in the Oyo State Public Service. Unpublished doctoral dissertation, University of Ibadan, Ibadan, Nigeria.

Ogundele, O., Adeyinka, F. M., Adeoti, J. O., \& Chete, L. N. (2014). Industrial development and growth in Nigeria lessons and challenges. Retrieved from http://file:///C:/Users/User/Downloads/wp2014-019.pdf

Olatokun, W., \& Kebonye, M. (2010). e-Commerce technology adoption by SMEs in Botswana. International Journal of Emerging Technologies and Society, 8(1), 42 - 56.

Ou, C., \& Haynes, G. W. (2006). Acquisition of additional equity capital by small firms - Findings from the National Survey of Small Business Finances. Small Business Economics, 27(1), 157-168. http://dx.doi.org/10.1007/s11187-006-0009-8

Oyelaran-Oyeyinka, O. (1997). Industrial technology policy-making and implementation in Nigeria: an assessment. Ibadan: Nigerian Institute of Social and Economic Research (NISER).

Oyelaran-Oyeyinka, B. (2010). FSS 2020 international conference SME: Issues, challenges and prospects. Retrieved from http://www.cenbank.org/fss/wed/SME_Issues, \%20Challenges\%20and\%20Prospects_Oyeyinka\%20Ban ji.pdf

Page, J., \& Söderbom, M. (2012). Is small beautiful? Small enterprise, aid and employment in Africa (2012/94). Retrieved from UNU World Institute for Development Economics Research website: http://www.wider.unu.edu/publications/working-papers/2012/en_GB/wp2012-094/

Peteraf, M. A. (1993). The cornerstones of competitive advantage: A resource-based view. Strategic Management Journal, 14(1), 179-191. http://dx.doi.org/10.1002/smj.4250140303

Reiss, F. (2006, December 11). Why small businesses fail. Retrieved from http://www.publishinggame.com/art_whysmallbusinessesfail.htm

Revilla, A. J., \& Fernández, Z. (2012). The relation between firm size and R\&D productivity in different technological regimes. Technovation, 32(11), 609-623. http://dx.doi.org/10.1016/j.technovation.2012.06.004 
Small and medium scale business performance in Nigeria

Roos, J., Roos, G., Dragonetti, N., \& Edvinsson, L. (1997). Intellectual capital: Navigating the new business landscape. Houndmills, Basingstoke: Macmillan Business.

Royal, C., \& ODonnell, L. (2008). Differentiation in financial markets: the human capital approach. Journal of Intellectual Capital, 9(4), 668-683. http://dx.doi.org/10.1108/14691930810913212

Sanusi, J. O. (2003). Overview of governments efforts in the development of SMES and the emergence of small and medium industries equity investment scheme (SMIEIS). Retrieved from Central Bank of Nigeria website: http://www.cenbank.org/OUT/SPEECHES/2003/GOVADD-10BJUNE.PDF

Schiuma, G., Mason, S., \& Kennerley, M. (2007). Assessing energy within organisations. Measuring Business Excellence, 3(11), 69-78. http://dx.doi.org/10.1108/13683040710820764

Seleim, A., Ashour, A., \& Bontis, N. (2004). Intellectual capital in Egyptian software firms. The Learning Organization, 11(4/5), 332-346. http://dx.doi.org/10.1108/09696470410538233

Sharifirad, M., \& Ataei, V. (2012). Organizational culture and innovation culture: Exploring the relationships between constructs. Leadership \& Organization Development Journal, 33(5), 494-517. http://dx.doi.org/10.1108/01437731211241274

Stewart, T. A. (1997). Intellectual capital: The new wealth of organizations. New York: Doubleday / Currency.

Subramaniam, M., \& Youndt, M. A. (2005). The influence of Intellectual Capital on the Types of Innovative Capabilities. Academy of Management Journal, 48, 450-463. http://dx.doi.org/10.5465/AMJ.2005.17407911

Sveiby, K. E. (1997). The new organizational wealth: Managing \& measuring knowledge-based assets. San Francisco: Berrett-Koehler Publishers.

Tan, H. P., Plowman, D., \& Hancock, P. (2007). Intellectual capital and financial returns of companies. Journal of Intellectual Capital, 8(1), 76-95. http://dx.doi.org/10.1108/14691930710715079

Vaona, A., \& Pianta, M. (2008). Firm size and innovation in European manufacturing. Small Business Economics, 30(3), 283-299. http://dx.doi.org/10.1007/s11187-006-9043-9

Wang, W., \& Chang, C. (2005). Intellectual capital and performance in causal models: Evidence from the information technology industry in Taiwan. Journal of Intellectual Capital, 6(2), 222-236. http://dx.doi.org/10.1108/14691930510592816

Wang, H., \& Wu, C. (2011). Green growth as the best choice for Chinese small and medium enterprises in sustainable development. Asian Social Science, 7(5), 81-84. http://dx.doi.org/10.5539/ass.v7n5p81

Wiklund, J., \& Shepherd, D. (2005). Entrepreneurial orientation and small business performance: a configurational approach. Journal of Business Venturing, 20(1), 71-91. http://dx.doi.org/10.1016/j.jbusvent.2004.01.001

Wu, W., Chang, M., \& Chen, C. (2008). Promoting innovation through the accumulation of intellectual capital, social capital, and entrepreneurial orientation. R\&D Management, 38, 265-277.

Zerenler, M., Hasiloglu, S. B., \& Sezgin, M. (2008). Intellectual capital and innovation performance: Empirical evidence in the Turkish automotive supplier. Journal of Technology Management \& Innovation, 3(4), 31-40. http://dx.doi.org/10.4067/S0718-27242008000200003

Zulkifli-Muhammad, M., Char, A., Yasoa, B., \& Hassan, Z. (2010). Small and medium enterprises (SMEs) competing in the global business environment: A case of Malaysia. International Business Research, $3(1), 66-75$. 
Eniola, A. A., Entebang, H., \& Sakariyau, O. B. 